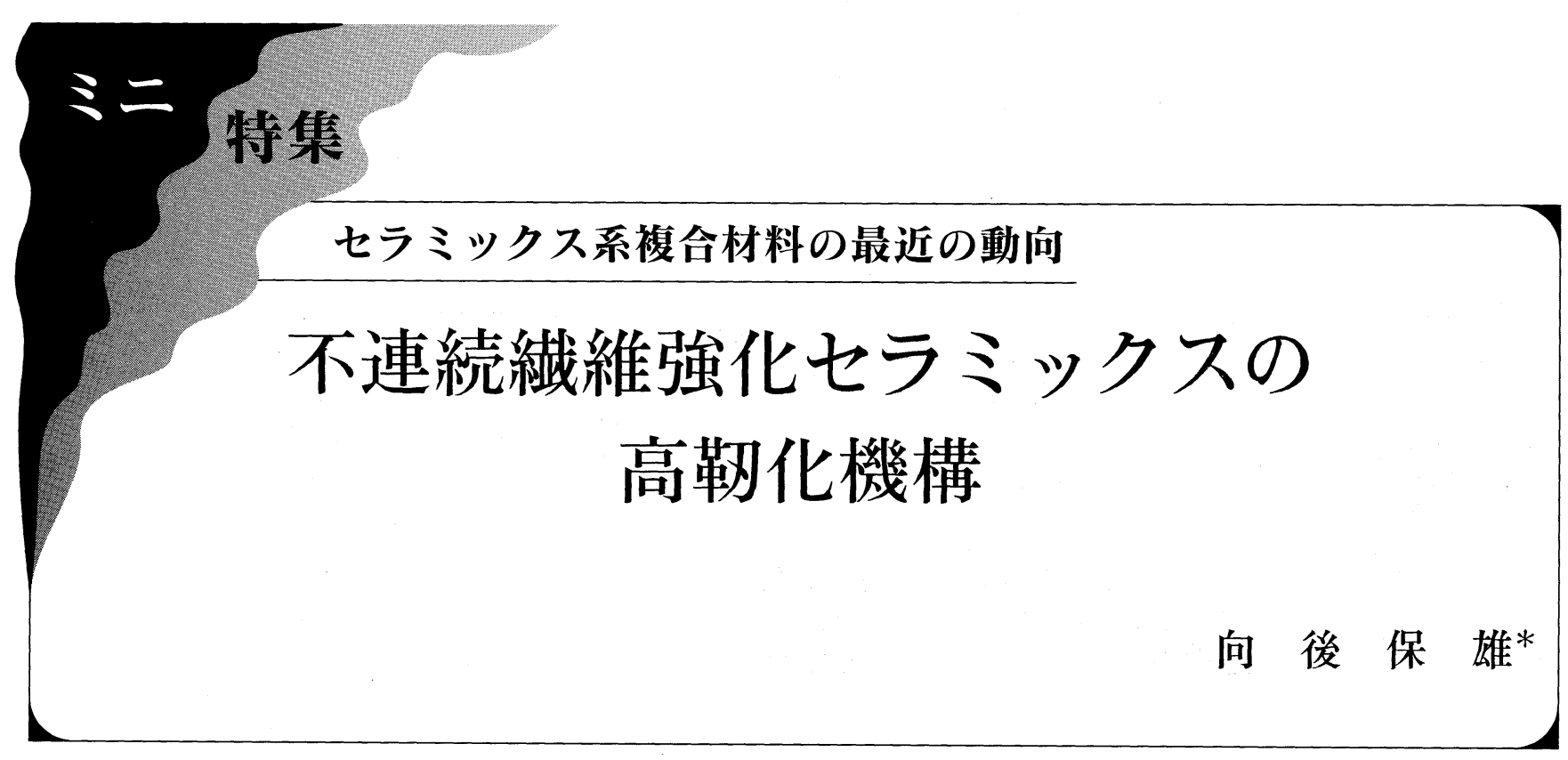

1. はじめに

構造用セラミックスは弾性率や強度に優れた材料であり， 金属材料江不足している耐熱特性や化学的安定性を兼亦備兄 ていることから, 近い将来の工業用材料としての用途拡大が 期待されている。一方, セラミックスは一般破壊勒性が小 さいことから, 構造材料として考兄た場合には信頼性に乏し いといら大きな欠点を合わせ持っている。このため，これま で製造プロセスの改良によってセラミックス中の欠陷を除去 し, 結晶粒を緻密化することにより機械的特性を改善する試 みがなされてきた，一方，勒性向上に対するもら一つのアプ ローチとして，セラミックス中に $\mathrm{SiC}, \mathrm{Si}_{3} \mathrm{~N}_{4}, \mathrm{Al}_{2} \mathrm{O}_{3}$ などの セラミックス繊維やセラミックスウイスカなどの第二相を複 合化したセラミックス系複合材料が検討されている(1)-(3).

セラミックス系複合材料は連続䋐維で強化する場合(以下, 連続瀻維系) と, 粒子, 短緘維, ウイスカ等の不連続な第二 相により強化したもの(以下, 不連続系)がある. 一般に連続 緎維で強化した場合の方が高強度ならびに高勒性な材料を得 られるが，強化材ならび製造プロセスのコストが高い，一 方, 不連続系の場合, 従来のモノリシックなセラミックスと 同種の製造プロセスをとることも可能であるため, 連続紻維 系に比べ低コストでの製造が可能である。また，材料特性の 異方性が小さいことから，部材を製造するに当たっては従来 の手法が流用できる点も大きな利点の一つである。このた め, これまで不連続系のセラミックス系複合材料扎いてる 勒性を向上するための実験的・理論的研究が多数行われてき た．以下ではこれらの研究成果をもとに不連続系に打ける高 勒化機構について述べる。

\section{2. 高勒化機構の分類}

セラミックスを高勒化する機構は大別すると応力遮蔽効果 を伴うものと応力遮蔽効果を伴わないものがある(4). 応力遮 蔽効果とは, き裂周囲の力学的環境がき裂の進展に伴って変 化し，き裂先端での応力集中を緩和する効果をもたらすもの である. 一方, 応力遮蔽効果を伴わない機構は, き裂の進展 経路が変化したり, き裂進展の妨げとなる第二相などの存在 により勒性が向上する機構である.

\section{（1）応力遮蔽効果による高勒化}

応力遮蔽効果を伴万高勒化機構としては, 図 1(a) 飞示す ように，セラミックスの結晶粒がき裂をブリッジングする場 合(5)-(7)や, 図 1(b)に示すよらに, 第二相として添加した緎 維やウイスカがブリッジングする場合(8)-(11)があげられる. これらは, 外力によって開口しようとするき裂面の変位をブ リッジングした結晶粒, 緎維拉よびウイスカなどが拘束し, き裂先端での応力拡大係数を低下させる機構である。また， 図1(c)に示与微視き裂(マイクロクラック)(12)(13)のように, き裂周囲に膨張歪みを伴う領域を生ずる場合には，周囲の膨 張歪みが発生していない領域からの拘束を受け, この拘束力 がき裂面を压縮する力として作用することによりき裂先端で の応力拡大係数を低下させる.

マイクロクラックと同様の機構は $\mathrm{ZrO}_{2}$ の相変態による高 勒化に扔いて子発現される。この機構では材料中をき裂が進 展寸る際, き裂先端に打恀る応力集中に上り $\mathrm{ZrO}_{2}$ の正方晶 から単斜晶へのマルテンサイト变態を誘起する(応力誘起相 変態)。この変態伴い $\mathrm{ZrO}_{2}$ は打よそ $4 \%$ の体積膨張を生ず

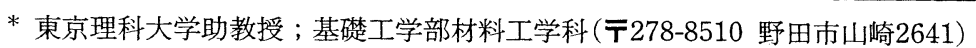

Toughening Mechanisms of Discontinuous Fiber Reinforced Ceramics; Yasuo Kogo(Faculty of Industrial Science and Technology, Science University of Tokyo, Noda)

Keywords: tougheness, ceramic matrix composites, bridging, microcracking, transformation, deflection, bowing 1999年 2 月 3 日受理 

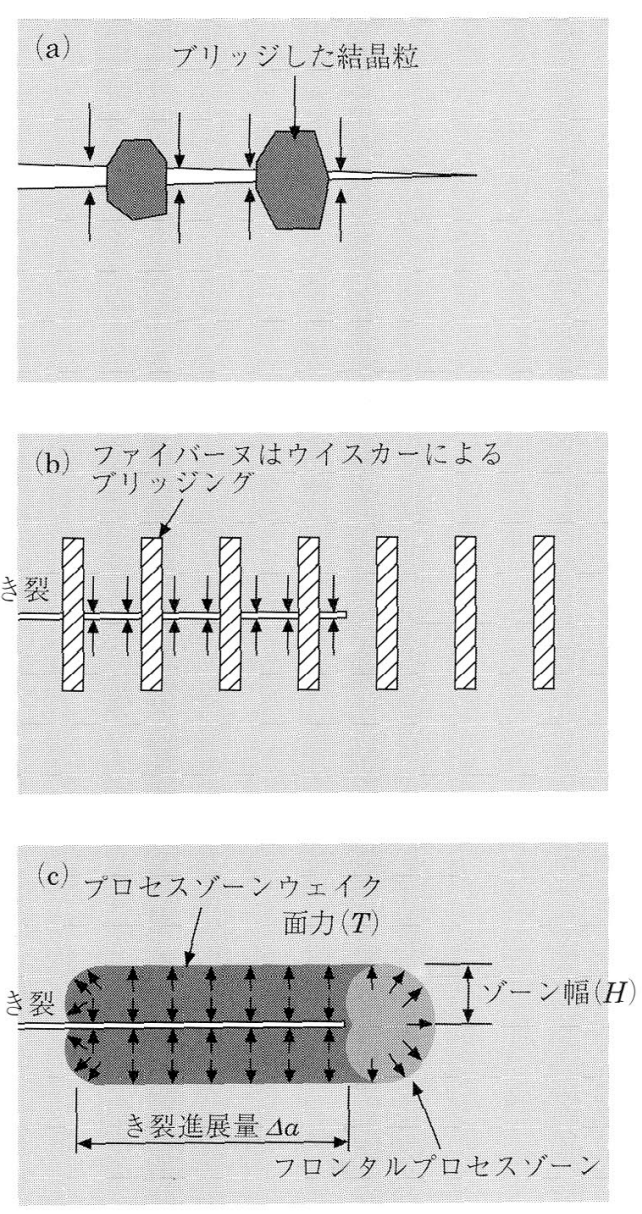

図 1 応力遮蔽効果に上る高勒化機構.
(a) 結晶粒によるブリッジング,
(b) ファイバー
又はウイスカーによるブリッジング，(c)-マイク ロクラック。

ることから(14)，き裂周囲の变態を生じた領域(変態領域)に は膨張歪多が残留与る。この膨張歪みがマイクロクラックの 場合同様周囲からの拘束を受け，き裂が開口寸るのを拘束す る、これは応力遮蔽効果の一種ではあるが，き裂の進展に伴 って材料自身が变化与る点に拈いて独特の機構である.この 機構の特徵は, $\mathrm{ZrO}_{2}$ 単体の場合はもらろんのこと, $\mathrm{ZrO}_{2}$ を 怹のマトリクス中に分散した場合にも有効であるため, 不連 続系のセラミックス系複合材科の第二相として利用与ること ができる点炏る。

いずれの機構においても，応力遮蔽効果はき裂先端に打子 る応力桩大係数 $\left(K_{\text {tip }}\right)$ の臨界条件を変化させるものではな く，き裂への外力の影響を軽減する(遮蔽する)効果である.

\section{（2）応力遮蔽効果以外の高勒化}

一方, 底力遮蔽効果を伴わない高勒化の機構としては, 図 2(a)に示すよらなき裂の偏向（ディフレクション）による効 果(16)があげられる。すなわち，き裂が偏向すること注り マクロ的にはモードの負荷状態にあるき裂が，ミクロ的に は混合モード状態となるため実際に有效な応力拡大係数 $\left(K_{\text {eff }}\right)$ が低くなる効果である。これは，応力遮蔽効果の場合 のよらに外力を妨げるような力が発生する効果ではなく, き (a)

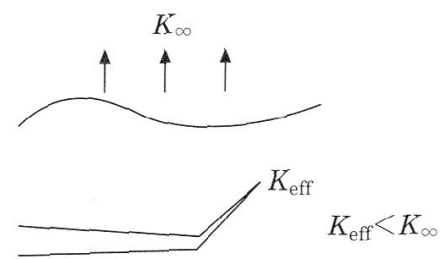

(b)

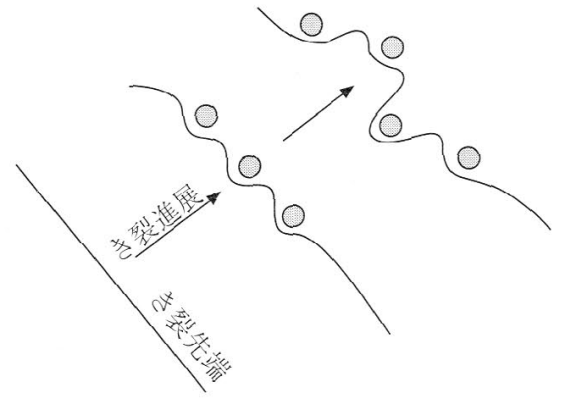

図2 応力遮蔽効果を伴わない高勒化機構.
(a)クラック・ディフレクション，(b) クラック ・ボウイング.

裂形状によって外力による応力拡大係数の実効值が低下する 効果である。また，図2(b)に示したき裂の湾曲(ボウイン グ)(17)(18)では，第二相が存在することによりき裂先端の形 状が直線から曲線に变化するため, き裂先端が直線の場合に 比べき裂進展の抵抗が増加する機構である。したがって, 応 力遮蔽効果を伴わない高勒化機構はマクロ的に見た場合，き 裂先端に括ける応力桩大係数 $\left(K_{\text {tip }}\right)$ の臨界值が増加与る機構 である。

\section{(3) マルチタフニング}

一般にセラミックスの高勒化では上記に示した機構が単独 で作用するわけではなく，いくつかの機構が同時に作用して 勒性の向上が達成されており，マルチタフニングと呼ばれて いる、実際には意㘠的にマルチタフニングを制御する場合よ り当，結果としてマルチタフニングルなっている場合の方が 多いよらである。マルチタフニングを積極的に利用している 代表例として， $\mathrm{ZrO}_{2}$ とウイスカを同時に添加することが試 みられ，勒性の制御が可能であることが示されている。ウイ スカのみによる高勒化に比べ $\mathrm{ZrO}_{2}$ を添加与ることにより高 い勒性が得られて特り ${ }^{(19)(20),}$ 理論的にもマルチタフニング が可能であることが示されている(21).

\section{3. 高靭化理論}

セラミックスの高勒化理論の研究は, 不連続系の $\mathrm{CMC}$ 一 も注淁そのま来適用でき, 応力遮蔽効果の有無でそれぞれの 理論が適用されている、以下では, 紙面の都合から, 主に応 力遮蔽効果がある場合についてまとめてみた。 


\section{（1） $\boldsymbol{R}$ 曲線挙動}

応力遮蔽効果による高勒化機構が作用した場合, その特徵 的な挙動としてき裂進展抵抗が増加する $R$ 曲線挙動(Resistance curve behavior)が認められる。 $R$ 曲線挙動に打いて は, き裂の進展量 $(\Delta a)$ の変化と, 外力とき裂長さより求め られる応力拡大係数 $(K)$ の関係が,

$$
K^{\infty} \propto(\Delta a)^{n}
$$

なる関係で近似される(22)-(24)。ここで， $n$ は $R$ 曲線の形状 に関与する定数である.このため, セラミックスの高勒化挙 動の研究に拈いては， $R$ 曲線挙動を測定することにより材料 の高勒化挙動が論じられている(25)-(27)。ここで測定される $K^{\infty}$ はき裂先端に打ける応力拡大係数 $\left(K_{\text {tip }}\right)$ と高勒化機構に よる応力拡大係数への寄与分 $(\Delta K)$ を用いて,

$$
K^{\infty}=K_{\text {tip }}+\Delta K
$$

と示すことができる(4).

式(1)に示されるような $R$ 曲線挙動を示す材料の破壊勒 性試験を行った場合，実験より求められる破壊勒性值は $R$ 曲線挙動の形状に依存することになる。これは図 3 に模式的 に示すように，き裂が安定成長から不安定成長に遷移寸るき 裂長さが, 式( 1 ) と,

$$
K_{\infty}=Y \sigma \sqrt{\pi\left(a_{0}+\Delta a\right)}
$$

の接点として求められることより定性的に理解される(28). ここで， $Y$ はき裂の形状係数， $\sigma^{\infty}$ は負荷された応力， $a_{0}$ は 初期き裂長さ， $\Delta a$ はき裂進展長さである.

$R$ 曲線が存在した場合の実験より求められる最大応力 $\left(\sigma_{\mathrm{f}}\right)$ は，不安定破壊に遷移するき裂進展長さ $\left(\Delta a_{\mathrm{f}}\right)$ を用いて，

$$
\left(\sigma_{f}\right)^{2}=\frac{\left(K_{\infty}\right)^{2}}{Y^{2} \pi\left(a_{0}+\Delta a\right)}
$$

と示すことができる，ここで，図 3 に示したように A, B 2 種類の $R$ 曲線が存在した場合, 初期き裂長さ $\left(a_{0}\right)$ と最大応 力 $\left(\sigma_{\mathrm{f}}\right)$ を用いて求められる破壊勒性値は図中に示したように 異なる値となる。したがって， $R$ 曲線を取る材料に扣いて は, 実験で得られる最大荷重より求めた破壊勒性值はき裂進 展開始の応力拡大係数を意味するものではなく, 高勒化機構 に対応した $R$ 曲線挙動拉よび試験片形状に依存する $R$ 曲線 挙動をパラメータとして含む值である。

先に述べたように， $R$ 曲線挙動をとる材料に打けるき裂の 進展開始条件は $K_{\text {tip }}$ が臨界値 $\left(K_{\text {tip }}^{\mathrm{C}}\right)$ に達することであり， マ

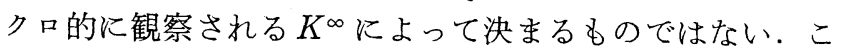
のような挙動は $K^{\infty}$ と $K_{\text {tip }}$ を独立に測定することにより実 験的にも検証されている(29). 図 4 は, 外力とき裂長さから 求められる $K^{\infty}$ とは独立に, コースティック法によってき 裂先端での $K_{\text {tip }}$ を測定したものである。き裂の進展ととも に $K^{\infty}$ が増加するのに対し， $K_{\text {tip }}$ はき裂長さによらず一定值 を示している.

\section{（2）応力論による $\boldsymbol{R}$ 曲線挙動の解析}

$R$ 曲線挙動を伴う場合の解析の中で, ブリッジングによる 場合につていは, 連続繊維強化セラミックスに拈いて多数の 研究がなされている. 不連続系に特有な解析としては, $\mathrm{ZrO}_{2}$ の相変態やマイクロクラックの発生に伴いき裂周囲に

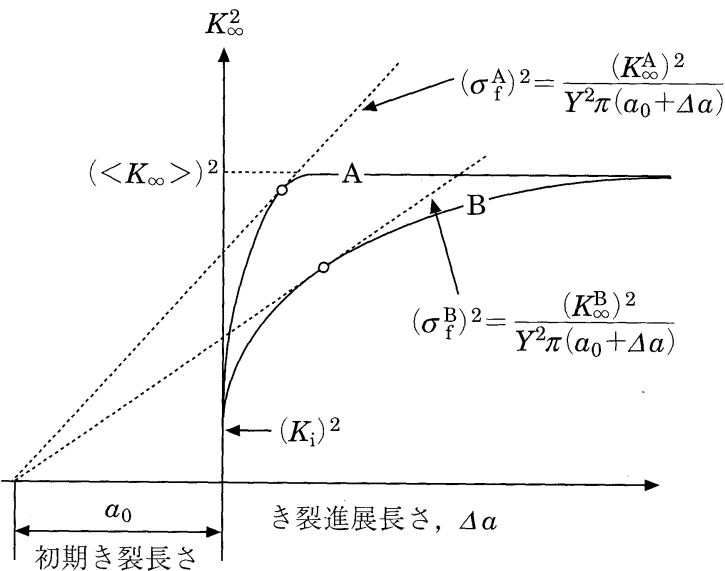

$$
\begin{aligned}
& K_{\mathrm{C}}^{\mathrm{A}}=Y \sigma_{\mathrm{f}}^{\mathrm{A}} \sqrt{\pi a_{0}} \\
& K_{\mathrm{C}}^{\mathrm{B}}=Y \sigma_{\mathrm{f}}^{\mathrm{B}} \sqrt{\pi a_{0}}
\end{aligned} \rightarrow K_{\mathrm{C}}^{\mathrm{A}}>K_{\mathrm{C}}^{\mathrm{B}}
$$

図 3 実験より求められる破壊勒性値と $R$ 曲線の関係.

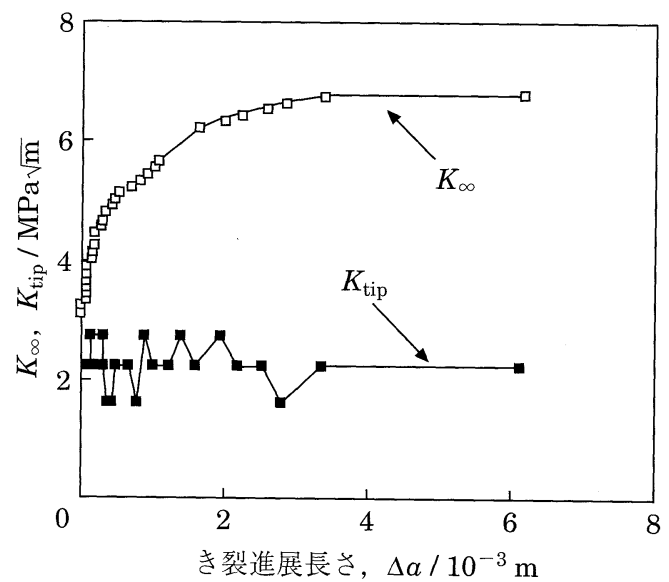

図 4 外力とき裂長さより求められる応力拡大係数 $\left(K_{\infty}\right)$ とコースティックス法によって求められる き裂先端での応力拡大係数 $\left(K_{\mathrm{tip}}\right)$ の関係.

膨張歪みが発生する場合についての解析である，それらの中 で代表的なものは McMeeking らによる応力論(30) と Budiansky らのエネルギー論(31)であり，両者が等価な解析 であることも示されている，そこでここでは，応力論につい てその概要を述べる.

McMeeking らの応力論のモデルは, 当初 $\mathrm{ZrO}_{2}$ の相変態 による高勒化機構を解析するために提案された。 しかし，こ の手法は $\mathrm{ZrO}_{2}$ 単体に限らず不連続系のセラミックス基複合 材料への適用が可能である.

図1(c)で示したようにき裂先端への応力集中によってき 裂先端に体積膨張を生ずる領域(フロンタルプロセスゾーン) を形成する．この領域は，き裂の進展に伴ってき裂面周囲に 残留し，体積膨張を生じた層（プロセスゾーンウェイク）を形 成する，先に述べたように，これらの領域は残留する体積膨 張のため, 周囲からの拘束を受ける. 力学的にはフロンタル プロセスゾーン持よびゥェイクとこれら以外の領域との境界 面に面力 $(T)$ が作用している環境となっている。

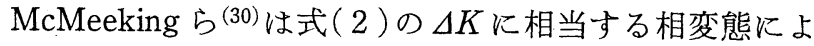




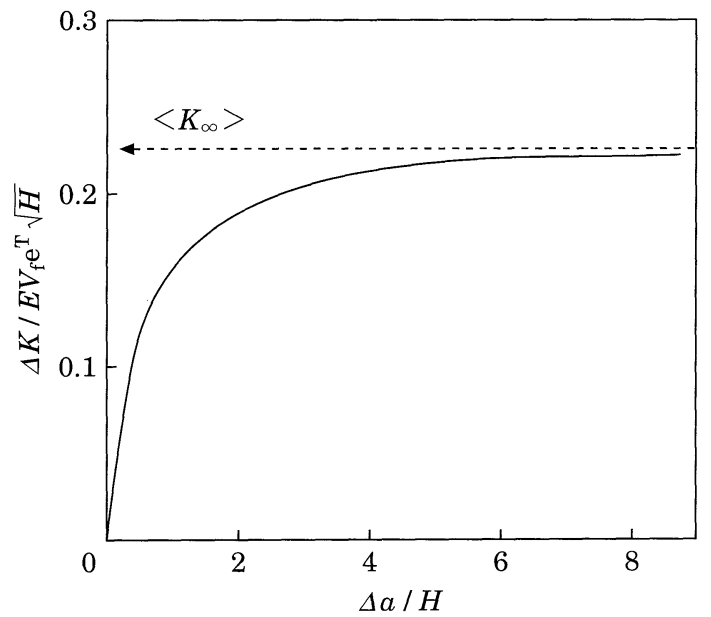

図 5 解析より求められる $R$ 曲線挙動.

る応力桩大係数への寄与分を, Bueckner の示した重み付け 関数法(Weight function method) (32)を用いて，

$$
\Delta K=\int_{\partial S} T h \mathrm{~d} s
$$

と示した. ここで, $s$ は変態領域境界面に沿って積分するこ とを意味している。また，式 $(5)$ 中, $T$ は変態領域境界面 に発生した面力であり， $h$ は Bueckner が定義した重み付け 関数(Weight function)である.

上記手法によって，フロンタルプロセスゾーンのみが存在 する場合には相変態がき裂先端に打ける応力拡大係数を低下 させる効果として寄与しないことを示した，また，き裂の進 展に伴いプロセスゾーンウェイクが形成され，これに伴って 図 5 に示すように $\Delta K$ が上昇する $R$ 曲線挙動を取ることを 示し, 応力遮蔽効果による高勒化機構の解析的な裏付けを与 えた。

\section{4.おおりに}

以上のように，不連続系のセラミックス基複合材料の高勒 化機構は理論的・実験的にある程度体系化されてきた。しか し，実際の応用を前提とする場合には考慮しなければならな いことが多数残されているよらに思われる.

その一例としては， $R$ 曲線挙動によって勒性が向上する材 料をどのように利用するかといら問題がある．R曲線による 勒性向上を利用することは，材料中でき裂が進展開始した以 後も荷重を負担することが前提となり，従来の設計ではあり 得ない考方を用いることになる．したがって，この種の材 料を利用するための設計手法ならびに設計基準についても， 十分検討されなければならない。

また，設計以前の問題として，R曲線挙動による高勒化が すべての荷重状態で同等に作用するものではないといら点が ある、実際の構造では，これまで多くの実験で検討されてい るような開口型の荷重状態になることはまれであり，他のモ
一ドも含んだ混合モードになることが一般的である。しか し, ここで示した高勒化機構には異方性があるため, 開口モ ードでの高勒化注ど他のモードでの高勒化が期待できない場 合もあることが知られている(32).

これらを始めとする未解決の間題は，実用化のための開発 と平行して実験的・理論的に明らかにされるべき問題であ り, 今後の発展が期待される.

\section{文献}

(1) P. F. Becher and G. C. Wei: J. Am. Ceram. Soc., 67(1984), C-267.

(2) P. D. Shalek, J. J. Petrovic, G. F. Hurley and F. D. Gac: Am. Ceram. Soc. Bull., 65(1986), 351.

( 3 ) M. Bengisu, O. T. Inal and O. Tosyali: Acta Metall., 39(1991), 2509.

（4）香川 豊, 八田博志 : セラミックス基複合材料, アグネ承風 社, (1990), 120.

( 5 ) P. L. Swanson, C. J. Fairbanks, B. R. Lawn, Y.-W. Mai and B. J. Hockey: J. Am. Ceram. Soc., 70(1987), 279.

(6) Y.-W. Mai and B. R. Lawn: ibid., 70 (1987), 289.

( 7 ) S. J. Bennison and B. R. Lawn: Acta Metall., 37 (1989), 2659.

( 8 ) J. Aveston, G. A. Cooper and A. Kelly: in "The Properties of Fiber Composites", Conf. Proc., National Phys. Lab., IPC Science \& Technology Press, Surrey, England, (1971), 15.

(9) D. B. Marshall, B. N. Cox and A. G. Evans: ibid., 33(1985), 2013.

(10) B. Budiansky, J. W. Hutchinson and A. G. Evans: J. Mech. Phys. Solids, 34(1986), 167.

(11) P. F. Becher, C.-H. Hsueh, P. Angelini and T. N. Tiegs: J. Am. Ceram. Soc., 71(1988), 1050.

(12) A. G. Evans and K. T. Faber: ibid., 67 (1984), 255.

(13) J. W. Hutchinson: Acta Metall., 35(1987), 1605.

(14) W. M. Kriven, W. L. Fraser and S. W. Kennedy: Adv. Ceram., 3(1981), 81.

(15) K. T. Faber and A. G. Evans: ibid., 31(1983), 565.

(16) K. T. Faber and A. G. Evans: ibid., 31 (1983), 577.

(17) F. F. Lange: Phil. Mag., 22(1970), 983.

(18) A. G. Evans: ibid., 26(1972), 1327.

(19) P. F. Becher and T. N. Tiegs: J. Am. Ceram. Soc., 70(1987), 651.

(20) K. Ikeda and T. Kishi: Eng. Fract. Mech., 40(1991), 801.

(21) 向後保雄, 香川 豊, 八田博志, 岸 輝雄 : 日本金属学会誌, 58(1994), 8.

(22) R. F. Krasuse, Jr.: J. Am. Ceram. Soc., 71(1988), 338.

(23) R. F. Krause, Jr., E. R. Fuller, Jr., and J. F. Rhodes: ibid., 73(1990), 559.

(24) J. Homeny and W. L. Vaughn: ibid., 73(1990), 2060.

(25) L. R. F. Rose and M. V. Swain: J. Am. Ceram. Soc., 69 (1986), 203.

(26) M. V. Swain: J. Mater. Sci. Lett., 5(1986), 1313.

(27) D. B. Marshall and M. V. Swain: J. Am. Ceram. Soc., 71(1988), 399.

(28) A. H. Heuer: J. Am. Ceram. Soc., 70(1987), 689.

(29) Y. Kogo, Y. Kagawa and H. Hatta: Materials Science and Engineering A, 176(1994), 165.

(30) R. M. McMeeking and A. G. Evans: J. Am. Ceram. Soc., 65 (1982), 242.

(31) B. Budiansky, J. W. Hutchinson and J. C. Lambropoulos: Int. J. Solids Structures, 19(1983), 394.

（32）向後保雄, 香川 豊, 八田博志：日本金属学会誌, 56(1992), 1280. 